\title{
Research on the Relationship between Managerial Overconfidence and Corporate $R \&$ D Investment in the Context of Financing Constraints
}

\author{
Tongying Liang, Xiangtian Mo \\ School of Business Administration, South China University of Technology, Guangzhou, China \\ Email: 415929266@qq.com
}

How to cite this paper: Liang, T.Y. and Mo, X.T. (2017) Research on the Relationship between Managerial Overconfidence and Corporate R \& D Investment in the Context of Financing Constraints. Open Journal of Business and Management, 5, 22-33.

http://dx.doi.org/10.4236/ojbm.2017.51003

Received: November 18, 2016

Accepted: December 5, 2016

Published: December 8, 2016

Copyright $\odot 2017$ by authors and Scientific Research Publishing Inc. This work is licensed under the Creative Commons Attribution International License (CC BY 4.0).

http://creativecommons.org/licenses/by/4.0/

\begin{abstract}
Using the data of Chinese listed companies from 2012 to 2014, this paper empirically tests the relationship between managerial overconfidence and corporate R \& D investment in the context of financing constraints by the method of multiple regression analysis, and further tests the impact of ownership type on the relationship. We find that: 1) Compared with the companies with weak financing constraints, the positive relationship between managerial overconfidence and corporate $\mathrm{R} \& \mathrm{D}$ investment in the companies with strong financing constraints is stronger; 2) In the context of strong financing constraints, compared with the state-owned companies, the positive relationship between managerial overconfidence and corporate $\mathrm{R} \& \mathrm{D}$ investment in the non-state-owned companies is stronger.
\end{abstract}

\section{Keywords}

Financing Constraints, Managerial Overconfidence, Corporate R \& D Investment, Ownership Type

\section{Introduction}

With China's economic growth into the new normal, the "factor-driven" development model with a large amount of resource consumption has been unable to adapt to the trend of the times and economic transformation is imperative, so "innovation driven" will be the only way for China's economic development. Firms are the main body of innovation and the factors that drive their innovation are various, among which two kinds of important factors are: managers and capital. Managers as the strategy makers directly determine whether the firms will pursue innovation activities with high income and high risk. With the development of behavioral finance, more and more scholars begin to pay attention to the influence of managerial irrational behavior on corporate innovation activities, especially managerial overconfidence. In addition, innovation ac- 
tivities have the characteristics of high income, high risk and long cycle, and the entire process requires a large amount of fund to support. But the capital market of our country starts late and develops slowly; there are many imperfections, such as the problem of information asymmetry and so on; all these will lead to differences between corporate internal and external financing cost, so that domestic companies are facing strong or weak financing constraints. Scholars have already studied the influence of managerial overconfidence and financial constraints on R \& D investment respectively and obtained a more consistent conclusion. But there are no scholars to link the three together to study. Financing constraints can change the financing environment of R \& D investment, which affects managerial $\mathrm{R} \& \mathrm{D}$ decision-making. But when managers are overconfident and in the face of financing constraints, what is the impact of their unique "irrational" psychological effects on $\mathrm{R} \& \mathrm{D}$ decision-making process? This is a question worth pondering. Therefore, the main question discussed in this paper is the relationship between managerial overconfidence and $\mathrm{R} \& \mathrm{D}$ investment in the context of financing constraints.

The rest of the article is organized as follows: the second part is theoretical analysis and research hypothesis; the third part is research design, including data sources, samples, models and variables explanation. The forth part is analysis of empirical result. And the fifth part is research conclusion.

\section{Theoretical Analysis and Research Hypothesis}

Overconfidence is when people evaluate their ability or judge the probability of success, they will overestimate their actual level (sometimes called as "optimistic"). The studies of psychology suggest that humans (including experts) will show overconfidence in many aspects, but there are individual differences in the persistence and strength of confidence. Compared with ordinary people, managers are more prone to be overconfident. Managers are corporate strategy makers and their overconfident "irrational" psychology will have a significant impact on all aspects of companies. In R \& D investment, the psychological effects of overconfidence can be summarized as follows:

1) Self-motivation. Innovation activities have high returns, but also have high risk and uncertainty, and the cycle is relatively long. Rational managers tend to avoid risks and will not take the initiative to pursue innovation activities. In order to avoid this "short-sighted behavior" of managers, a certain external incentive is needed, e.g. managerial incentives (monetary compensation incentive or equity incentive). However, managers who are overconfident tend to overestimate the benefits of innovation and underestimate the risks, and believe that they will succeed in the end, which creates an intrinsic self-motivation to actively pursue innovation. Galasso and Simcoe (2010) measure CEO overconfidence with stock option execution and empirically examine the relationship between managerial overconfidence and corporate innovation. They find that overconfident CEOs overestimate the benefits of innovation and underestimate the risks. They will pursue more innovation and are more likely to lead the company to a new technology direction, especially in the competitive industry [1].

2) Innovation motivation. Before the "innovation-driven" development strategy is formally put forward, innovation has always been regarded as an important indicator of 
a company's competitiveness and potential. The success of innovation not only will bring high returns, but also bring a good reputation to the company. For managers, it is a manifestation of ability and vision. Galasso and Simcoe (2010) show that CEOs may show their ability of controlling the market through innovation [1]. In addition, David Hirshleifer, Angie Low, and Siew Hong Teoh (2012) also find that overconfident managers are more likely to adopt technology innovation programs as a way of demonstrating their management vision and capabilities [2]. So overconfident managers have stronger incentives to innovate. They are more confident in their ability of controlling and tend to pursue high-risk innovation.

3) Agency costs. Rational managers give up innovation activities for their own interest and thus violate the long-term interest of the shareholders, which will increase the cost of the principal agent. But overconfident managers are not. Fairchild (2005) finds that overconfident managers work harder, which will help alleviate agency problems [3]. Therefore, overconfident managers are more likely to consider the interest of shareholders and are loyal to the shareholders. They will actively pursue the high returns of $\mathrm{R} \& \mathrm{D}$ investment in order to improve the value of firm. From the perspective of project future cash flows, Gervais et al. (2011) show that overconfident managers tend to have higher expectations for future cash flows from investment projects and are more likely to make high-risk decisions, thereby reducing pay requirements [4]. Therefore, it is easier to motivate overconfident managers to conduct $\mathrm{R} \& \mathrm{D}$ activities than rational managers.

\subsection{The Impact of Financing Constraints}

In summary, managerial overconfidence can indeed promote corporate $\mathrm{R} \& \mathrm{D}$ investment, i.e. the relationship between the two is significantly positive. But when considering the factor of financing constraints, there will be any difference? Financing constraints are that in the imperfect financing market, due to large differences between internal and external financing costs, companies cannot pay external high financing costs, resulting in inadequate financing, which will cause that investment decisions are too dependent on internal fund and the investment level is below the optimal level [5]. The greater the difference between corporate internal and external financing costs, the higher the cost of acquiring fund from outside. In this situation, companies can freely use less money and face strong financial constraints. In the context of strong financing constraints, corporate innovation activities will face more severe challenges.This is because the shortage of fund will be more likely to result the termination of innovation activities at any time and the failure of innovation will not only bring about the loss of the fund but also affect the future development of firms, which is more full of uncertainty and risk. At this time the decision of investing in $\mathrm{R} \& \mathrm{D}$ undoubtedly is like a "gambling", which needs more courage and adventurous spirit. It has been shown [6] [7] [8] [9] that managers with extreme self-confidence are more entrepreneurial than rational managers and the entrepreneurialism characterized by innovation and risktaking is better able to overcome the effects of harsh environments, thus greatly promoting the company's internal technological innovation activities. Griffin and Tversky (1992) believe that with the increase of uncertainty the corporate investment environ- 
ment will be more complicated and changeable, but the overconfident managers are more interested in the arduous tasks, showing the "difficult effect" [10]. Therefore, compared to weak financing constraints, in the environment of strong financing constraints managers are facing more severe challenges in the R \& D investment, but the challenges can inspire overconfident manager's "difficult" effect and the psychological effect of self-motivation, innovation motivation and agency costs should be more prominent. At this point overconfident managers will be more determined to carry out $\mathrm{R} \& \mathrm{D}$ investment. To this end, we put forward the following hypothesis:

H1: Compared with the companies with weak financing constraints, the positive relationship between managerial overconfidence and corporate $\mathrm{R} \& \mathrm{D}$ investment in the companies with strong financing constraints is stronger.

\subsection{The Impact of Ownership Type}

China is constructing a socialist market economy with Chinese characteristics. It can be said to be a combination of planned economy and market economy. Although the government has always stressed the importance and irreplacement of the market mechanism, the country's economic development is still more subject to government's intervention, which is an indisputable fact. This creates special difference between the stateowned companies and the non-state-owned companies: In the process of economic transformation, the state-owned listed companies need to assume the government's social functions and will get some special care from the government. Managers in the state-owned company will pay more attention to the short-term performance and the political objectives. In addition, compared with the non-state-owned companies, the state-owned companies are more easily access to internal fund and external fund. This is because the state-owned companies have abundant assets and rich government relation resources, so they have more financing channels and bargaining power. When financing constraints are weak, two kinds of companies are easier to obtain fund from outside and the challenges of R \& D investment are relatively weak, so the special difference between companies will not be reflected and there is no significant difference in the relationship between managerial overconfidence and corporate R \& D investment. But in the context of strong financial constraints, compared with the non-state-owned companies, the state-owned companies can use some special financing channels to obtain financial support, and the $\mathrm{R} \& \mathrm{D}$ risk is not entirely taken by themselves, the government accordingly bear some of the risk. More importantly, the state-owned companies need to pay more attention to political objectives and the government will give some corresponding protection measures to allow them to survive in the fierce competition environment. So they will not be too persistent pursuit of innovation, when the fund is scarce, they can correspondingly reduce R \& D investment. But the non-stateowned companies are not so lucky, even in the case of strong financial constraints, they can only rely on their own efforts to survive and in the rapidly changing Internet era innovation is an important way out. At this time, compared with the state-owned companies, the challenges the non-state-owned companies face in the $\mathrm{R} \& \mathrm{D}$ investment are more serious. But this also inspire overconfident manager's "difficult effect" and they will be more determined to carry out R \& D investment. To sum up, the fol- 
lowing hypothesis is made:

$\mathrm{H} 2$ : In the context of strong financing constraints, compared with the state-owned companies, the positive relationship between managerial overconfidence and corporate $\mathrm{R} \& \mathrm{D}$ investment in the non-state-owned companies is stronger.

\section{Research Design}

\subsection{Sample Selection and Data Sources}

This paper takes all the A-share listed companies from 2012-2014 in Shenzhen and Shanghai Stock Market as the initial research objects. Then adopting the following screening process: 1) excluding financial and insurance listed companies; 2) excluding the companies whose data is missing and abnormal; 3) excluding Special Treatment and Particular Transfer companies. After the above screening process, a total of 6615 observations are obtained finally. The data mainly comes from CSMAR and WIND. The data is collected and integrated by EXCEL to ensure the efficiency and accuracy.

In order to test $\mathrm{H} 2$, we divide the whole sample into two subsamples according to the company's attributes, i.e. the state-owned company group and the non-state-owned company group. When the listed company's attribute is state-owned, state holding, collective enterprise or government agency, then it is identified as a state-owned company. When the listed company's attribute is private enterprise, Sino-foreign joint venture, wholly foreign-owned enterprise or other, it belongs to non-state-owned company. According to this standard, after the classification of 6615 observations, 4189 stateowned company observations and 2426 non-state company observations are finally obtained.

\subsection{Research Model and Variable Description}

According to previous studies, we use the multiple linear regression model with cross-term to test the hypotheses. The multiple regression model is shown below:

$$
\begin{aligned}
\mathrm{RD}= & \beta_{1}+\beta_{2} \mathrm{OC}+\beta_{3} \mathrm{FC}+\beta_{4} \mathrm{OC} * \mathrm{FC}+\beta_{5} \mathrm{SIZE}+\beta_{6} \mathrm{LEV} \\
& +\beta_{7} \mathrm{TBQ}+\beta_{8} \mathrm{ROA}+\mathrm{B}_{9} \mathrm{SHARE}+\beta_{10} \mathrm{DUA}+\varepsilon
\end{aligned}
$$

1) R \& D intensity (RD). The indicators of $R \& D$ investment are divided into two types: absolute indicator and relative indicator. The relative indicator is adopted by most scholars. So drawing on previous studies, this paper also selects R \& D intensity as the dependent variable, which is measured by the ratio of $\mathrm{R} \& \mathrm{D}$ expenses to the corporate main business income.

2) Managerial overconfidence (OC). The independent variable in this paper is managerial overconfidence. Although managerial overconfidence in recent years has received more and more scholars' attention, it is still very difficult to measure it reasonably and accurately. There are many methods of measuring overconfidence in the academic community, but it is difficult to find a consensus one. After the comprehensive consideration of various methods and the availability of data, we use the method of Hao Ying, Ye Bei and Rongwu Zhang [11] [12] [13] to measure managerial overconfidence, i.e. using the change of the number of shares held by the manager to measure managerial overconfidence. We believe that the decision is generally made by the executive 
team, so the managers in this article mainly refer to the executive team. If the number of shares held by the executive team in this year is more than that in the previous year, it is defined as overconfident and OC equals 1 . Otherwise it is defined as non-overconfident and OC equals 0 .

3) Financing Constraints (FC). We introduce financing constraints as an important dummy variable into the model and examine whether the relationship between managerial overconfidence and $\mathrm{R} \& \mathrm{D}$ investment is significantly different under different levels of financing constraints. There are many ways to measure financial constraints in the empirical research, including univariate indicator and multivariate index. Similarly, it is difficult to find an agreed-upon approach to measure financial constraints.

Hadlock and Pierce (2010) collect a random sample from 1995-2004 and refute the validity of the $\mathrm{KZ}$ index in measuring financial constraints by empirical tests [14]. They find that firm size (the natural logarithm of total assets) and firm age are effective indicators of the level of financing constraints and construct the SA index:

$$
\mathrm{SA}=-0.737 \text { Size }+0.043 \text { Size } 2-0.040 \text { Age }
$$

When the SA value is positive and greater, it indicates that financing constraints are weaker. Many scholars have begun to recognize this method. So in this paper, the SA index is used to measure the level of financing constraints the company faces. The reasons are as follows: First, the SA index does not contain endogenous financial variables. In addition, the SA index is relatively robust, as the other scholars have said, the financial constraints levels classified according to the SA index are consistent with those classified according to the WW index and investment-cash flow sensitivity. Because the variable of finance constraints is dummy, we first calculate the SA index of all the observations and then find the mean of them. If the SA index of a observation is less than the mean, it is defined as strong finance constraints and FC equals 1. Otherwise, it is defined as weak finance constraints and FC equals 0 .

4) According to the existing studies to choose the control variables, including: firm size, asset-liability ratio, Tobin q, return on assets, ownership concentration and duality (chairman and general manager). Chang X, Fu K and Low A [15], Ayyagari M, Demirguc-Kunt A and Maksimovic V [16] and other scholars believe that these variables will have a significant impact on corporate $\mathrm{R} \& \mathrm{D}$ investment. The definition of all the variables is shown in Table 1.

\section{Analysis of Empirical Result}

\subsection{Descriptive Statistics}

Using SPSS to carry out descriptive statistics of the sample data, exploring the quantitative relationship between the variables. All the samples were divided into overconfident group and non-overconfident group. From Table 2 we can see that the mean (0.0483) and the median (0.0375) of R \& D intensity in overconfident group are both greater than those in non-overconfident group, and the mean $\mathrm{T}$ test shows a significant difference in the means of the two groups, suggesting that overconfident managers are more enthusiastic about high-risk innovation activities. Then we further divide overconfident group into weak financing constraints group and strong financing constraints group. From Table 3 we can find that the mean (0.0483) and the median 
Table 1. Variable definitions.

\begin{tabular}{|c|c|c|}
\hline Variables & Code & Definitions \\
\hline $\mathrm{R} \& \mathrm{D}$ intensity & $\mathrm{RD}$ & $\mathrm{R} \& \mathrm{D}$ expenses/corporate main business income \\
\hline Overconfidence & OC & $\begin{array}{c}\text { If the number of shares held by the executive team } \\
\text { in this year is more than that in the previous year, OC equals } 1 \text {; } \\
\text { otherwise OC equals } 0\end{array}$ \\
\hline Financing constraints & FC & $\begin{array}{l}\text { If the } S A \text { index of a observation is less than the mean of } \\
\text { all observations, FC equals } 1 . \text { Otherwise FC equals } 0 .\end{array}$ \\
\hline Firm size & SIZE & Natural logarithm of total assets \\
\hline Asset-liability ratio & LEV & Total assets/Total liabilities \\
\hline Tobin q & TBQ & Market value of assets/The book value of assets \\
\hline Return on assets & ROA & Net profit/Average total assets \\
\hline Ownership concentration & SHARE & The proportion of the first largest shareholder \\
\hline Duality & DUA & $\begin{array}{l}\text { If the chairman and general manager are the same person, } \\
\text { DUA equals } 1 \text {; otherwise DUA equals } 0\end{array}$ \\
\hline
\end{tabular}

Table 2. Overconfident group and non-overconfident group.

\begin{tabular}{cccccccc}
\hline & \multicolumn{3}{c}{$\begin{array}{c}\text { Overconfident Group } \\
(\mathrm{N}=2430)\end{array}$} & \multicolumn{2}{c}{$\begin{array}{c}\text { Non-overconfident Group } \\
(\mathrm{N}=4185)\end{array}$} & $\begin{array}{c}\text { Mean } \\
\text { T test }\end{array}$ \\
\cline { 2 - 7 } & Mean & Median & Std. Dev. & Mean & Median & Std. Dev. & T value \\
\hline RD & 0.0483 & 0.0375 & 0.0457 & 0.0232 & 0.0235 & 0.0168 & $31.998^{* * *}$ \\
SIZE & 21.653 & 21.437 & 1.1331 & 21.942 & 21.762 & 1.2724 & $-9.266^{* * *}$ \\
LEV & 0.3467 & 0.3226 & 0.2021 & 0.4525 & 0.4508 & 0.2141 & $-19.784^{* * *}$ \\
TBQ & 0.0626 & 0.0569 & 0.0551 & 0.0409 & 0.0336 & 0.0762 & $12.303^{* * *}$ \\
ROA & 2.5631 & 2.0281 & 2.1661 & 1.9041 & 1.4961 & 1.5991 & $14.135^{* * *}$ \\
SHARE & 0.3421 & 0.3272 & 0.1401 & 0.3679 & 0.3554 & 0.1538 & $-6.828^{* * *}$ \\
DUA & 0.3461 & 0 & 0.4758 & 0.2327 & 0 & 0.4226 & $10.034^{* * *}$ \\
\hline
\end{tabular}

$* * *, * *,{ }^{*}$ Significant at the 0.01 level, 0.05 level and 0.10 level.

Table 3. Weak financing constraints group and strong financing constraints group.

\begin{tabular}{|c|c|c|c|c|c|c|c|}
\hline & \multicolumn{3}{|c|}{$\begin{array}{l}\text { Weak Financing Constraints Group } \\
\qquad(\mathrm{N}=1631)\end{array}$} & \multicolumn{3}{|c|}{$\begin{array}{l}\text { Strong Financing Constraints Group } \\
\qquad(\mathrm{N}=799)\end{array}$} & \multirow{2}{*}{$\begin{array}{c}\text { Mean } \\
\text { T test }\end{array}$} \\
\hline & Mean & Median & Std. Dev. & Mean & Median & Std. Dev. & \\
\hline $\mathrm{RD}$ & 0.0556 & 0.0417 & 0.0514 & 0.0336 & 0.0286 & 0.0253 & $11.435^{\star * *}$ \\
\hline SIZE & 21.043 & 21.058 & 0.5274 & 22.898 & 22.621 & 1.0136 & $-59.318^{\star * *}$ \\
\hline LEV & 0.2816 & 0.2509 & 0.1782 & 0.4795 & 0.4887 & 0.1816 & $-25.557^{\star * *}$ \\
\hline TBQ & 0.0629 & 0.0592 & 0.0526 & 0.0621 & 0.0511 & 0.0599 & 0.4069 \\
\hline ROA & 2.9792 & 2.3744 & 0.0599 & 1.7137 & 1.3054 & 1.4944 & $14.067^{\star * *}$ \\
\hline SHARE & 0.3279 & 0.3092 & 0.1287 & 0.3707 & 0.355 & 0.1569 & $-7.143^{\star \star \star}$ \\
\hline DUA & 0.4101 & 0 & 0.4921 & 0.2152 & 0 & 0.4112 & $9.6648^{* * *}$ \\
\hline
\end{tabular}

***, **, ${ }^{*}$ Significant at the 0.01 level, 0.05 level and 0.10 level. 
(0.0375) of R \& D intensity in strong financing constraints group are both greater than those in weak financing constraints group, and the mean $\mathrm{T}$ test also shows a significant difference in the means of these two groups, suggesting that in the context of financing constraints the positive impact of managerial overconfidence on corporate R \& D investment is more obvious. Although the above analysis results cannot prove the causal relationship between variables, to a certain extent this can reflect the possible relationship between variables, which is the evidence of the theoretical derivation of this paper.

\subsection{Multiple Regression Analysis}

In order to examine the impact of financing constraints on the relationship between managerial overconfidence and corporate R \& D investment after comprehensive consideration of various related factors, next we will use STATA to carry on the multiple regression analysis. Since this paper uses unbalanced panel data, we first need to identify the effect model used for the regression, i.e. the random effect model or the fixed effect model. According to the conventional method, the selection of the effect model is determined by the Hausman test. The result is shown in Table 4 . We can see that the result is significant at the $1 \%$ level $(p=0.0000)$, so the null hypothesis is rejected and the fixed effect model is used.

The multiple regression results of the fixed effect model are shown in Table 5. The first is the regression of all samples. The results in the first column of Table 5 show that

Table 4. The results of the Hausman test.

\begin{tabular}{cccc}
\hline & Chi-Sq. Statistic & Chi-Sq. d.f & Prob \\
\hline The effect model & 721.17 & 14 & 0.0000 \\
\hline
\end{tabular}

Table 5. The results of the multiple regression.

\begin{tabular}{|c|c|c|c|c|}
\hline & \multicolumn{3}{|c|}{ Dependent Variable $=\mathrm{RD}$} & \multirow{2}{*}{ Suest test } \\
\hline & (1) & (2) & (3) & \\
\hline \multirow{2}{*}{ OC } & $0.00195^{* * *}$ & $0.00104^{\star *}$ & $0.00307^{* * *}$ & \multirow{20}{*}{0.0036} \\
\hline & $(2.84)$ & $(1.00)$ & $(4.07)$ & \\
\hline \multirow{2}{*}{$\mathrm{FC}$} & $-0.00128^{\star}$ & $-0.00204^{\star}$ & $-0.00031^{\star}$ & \\
\hline & $(-1.27)$ & $(-1.43)$ & $(-0.24)$ & \\
\hline \multirow{2}{*}{$\mathrm{OC}^{\star} \mathrm{FC}$} & $0.00309^{* * *}$ & $0.00697^{\star * *}$ & $0.00268^{\star * *}$ & \\
\hline & $(3.56)$ & $(6.08)$ & $(2.17)$ & \\
\hline \multirow{2}{*}{ SIZE } & $0.00602^{* * *}$ & $0.00523^{* * *}$ & $0.00715^{\star * *}$ & \\
\hline & $(8.38)$ & $(4.94)$ & $(8.44)$ & \\
\hline \multirow{2}{*}{ LEV } & $-0.01513^{\star * *}$ & $-0.01375^{\star \star \star}$ & $-0.018799^{\star * *}$ & \\
\hline & $(-6.25)$ & $(-4.13)$ & $(-5.88)$ & \\
\hline \multirow{2}{*}{$\mathrm{ROA}$} & $-0.02182^{\star \star *}$ & $-0.01772^{\star \star \star}$ & $-0.04001^{\star * *}$ & \\
\hline & $(-6.44)$ & $(-4.16)$ & $(-7.04)$ & \\
\hline \multirow{2}{*}{ TBQ } & $-0.00042^{\star * *}$ & $-0.00038^{\star}$ & $-0.00035^{\star}$ & \\
\hline & $(-2.39)$ & $(-1.66)$ & $(-1.39)$ & \\
\hline \multirow{2}{*}{ SHARE } & $-0.00897^{\star *}$ & -0.00628 & $-0.00961^{*}$ & \\
\hline & $(-1.82)$ & $(-0.82)$ & $(-1.82)$ & \\
\hline \multirow{2}{*}{ DAULITY } & 0.00041 & $0.00073^{*}$ & -0.00033 & \\
\hline & $(0.53)$ & $(0.70)$ & $(-0.35)$ & \\
\hline $\mathrm{R}^{2}$ & 0.0543 & 0.0318 & 0.1645 & \\
\hline $\mathrm{N}$ & 6615 & 4189 & 2426 & \\
\hline
\end{tabular}

${ }^{\star * *},{ }^{* *},{ }^{\star}$ Significant at the 0.01 level, 0.05 level and 0.10 level. 
the regression coefficient of the cross-term $\left(\mathrm{OC}^{\star} \mathrm{FC}\right)$ is 0.00309 and the significant level reaches $1 \%$. The results show that compared with the companies with weak financing constraints, $1 \%$ increase of managerial overconfidence can more increase the R \& D investment by $0.309 \%$, which proves that in the context of financing constraints the positive relationship between managerial overconfidence and corporate R \& D investment is stronger and Hypothesis 1 is verified.

The second is the regressions of the state-owned company group and the non-stateowned company group. The results in the second and third column of Table 5 show that the regression coefficients of the cross-term $\left(\mathrm{OC}^{*} \mathrm{FC}\right)$ in the state-owned company group and the non-state-owned company group are 0.00697 and 0.00268 respectively and both of them reach the $1 \%$ significant level. However, we cannot directly compare 0.00697 and 0.00268 . It is also necessary to confirm whether there is a significant difference in these two coefficients. The Suest test was performed by STATA to test the difference between the two coefficients. The results in the fifth column of Table 5 show that the $\mathrm{p}$ value of the Suest test in the cross-term $\left(\mathrm{OC}^{\star} \mathrm{FC}\right)$ is $0.0036(<0.01)$, which proves that there is a significant difference in these two coefficients, i.e. 0.00697 is significantly greater than 0.00268 . Therefore, the results show that in the context of strong financing constraints, compared with the state-owned companies, the positive relationship between managerial overconfidence and corporate R \& D investment in the non-state-owned companies is stronger. Hypothesis 2 is also verified.

\subsection{Robustness Test}

We have used the SA index to measure the financial constraints and verified the hypotheses in the previous chapter. In order to make the research results more reliable, we use the univariate indicator (the dividend payout ratio) as the proxy variable of the financing constraints in the robustness test section to verify the hypotheses again. Since the higher the dividend payout ratio is, the weaker the financing constraint faced by the firm are, so we first calculate the mean of the dividend payout rate of all the observations. Then we define the observation whose dividend payout rate is below the mean as strong financing constraints and define the observation whose dividend payout rate is above the mean as weak financing constraints. The results of multiple regression using this proxy variable are shown in Table 6. As can be seen from Table 6, the sign of the regression coefficient are not changed and are still statistically significant. The results of the Suest test are also significant and the hypotheses of this paper are supported, so the conclusions remain the same, which indicates that the results of this paper have certain robustness.

\section{Research Conclusions}

This paper uses the data of A-share listed companies in Shenzhen and Shanghai Stock Market during the period of 2012-2014 to empirically test the relationship between managerial overconfidence and corporate $\mathrm{R} \& \mathrm{D}$ investment in the context of financing constraints, measuring managerial overconfidence by the change of the number of shares held by the manager and measuring the financing constraints by the SA index. The results show that compared with the companies with weak financing constraints, 
Table 6. The results of the robustness test.

\begin{tabular}{|c|c|c|c|c|}
\hline & \multicolumn{3}{|c|}{ Dependent Variable $=\mathrm{RD}$} & \multirow{2}{*}{ Suest test } \\
\hline & (1) & (2) & (3) & \\
\hline OC & $\begin{array}{c}0.00071^{\star *} \\
(0.95)\end{array}$ & $\begin{array}{c}0.00095^{\star *} \\
(0.85)\end{array}$ & $\begin{array}{c}0.00044^{* * *} \\
(0.68)\end{array}$ & \\
\hline $\mathrm{FC}$ & $\begin{array}{c}-0.00228^{*} \\
(-1.05)\end{array}$ & $\begin{array}{c}-0.00188^{\star *} \\
(-1.12)\end{array}$ & $\begin{array}{c}-0.00027^{* *} \\
(-0.21)\end{array}$ & \\
\hline $\mathrm{OC}^{\star} \mathrm{FC}$ & $\begin{array}{c}0.00249^{* *} \\
(2.52)\end{array}$ & $\begin{array}{c}0.00234^{* * \star} \\
(1.67)\end{array}$ & $\begin{array}{c}0.00114^{\star *} \\
(1.89)\end{array}$ & 0.0104 \\
\hline SIZE & $\begin{array}{c}-0.00136^{*} \\
(-1.45)\end{array}$ & $\begin{array}{c}-0.00414^{* *} \\
(-3.02)\end{array}$ & $\begin{array}{c}0.00332^{* * *} \\
(3.77)\end{array}$ & \\
\hline LEV & $\begin{array}{c}-0.01671^{* * *} \\
(-5.60)\end{array}$ & $\begin{array}{c}-0.01843^{* * *} \\
(-4.44)\end{array}$ & $\begin{array}{c}-0.01274^{* * *} \\
(-3.99)\end{array}$ & \\
\hline ROA & $\begin{array}{c}-0.02891^{* * *} \\
(-4.92)\end{array}$ & $\begin{array}{c}-0.03859^{* * *} \\
(-4.61)\end{array}$ & $\begin{array}{c}-0.01059^{* *} \\
(-1.82)\end{array}$ & \\
\hline TBQ & $\begin{array}{c}-0.00043^{* *} \\
(-1.89)\end{array}$ & $\begin{array}{c}-0.00057^{*} \\
(-1.98)\end{array}$ & $\begin{array}{c}0.00081^{* *} \\
(2.28)\end{array}$ & \\
\hline SHARE & $\begin{array}{c}-0.01666^{\star *} \\
(-2.76)\end{array}$ & $\begin{array}{c}-0.03505^{*} \\
(-3.76)\end{array}$ & $\begin{array}{c}0.00386^{*} \\
(0.74)\end{array}$ & \\
\hline DAULITY & $\begin{array}{c}0.00118^{*} \\
(1.32)\end{array}$ & $\begin{array}{c}0.00155^{*} \\
(1.21)\end{array}$ & $\begin{array}{c}0.00048^{*} \\
(0.56)\end{array}$ & \\
\hline $\mathrm{R}^{2}$ & 0.1711 & 0.1011 & 0.0947 & \\
\hline $\mathrm{N}$ & 5915 & 3912 & 2003 & \\
\hline
\end{tabular}

***, **, ${ }^{*}$ Significant at the 0.01 level, 0.05 level and 0.10 level.

the positive relationship between managerial overconfidence and corporate $\mathrm{R} \& \mathrm{D}$ investment in the companies with strong financing constraints is stronger. In addition, we further test the impact of ownership on this relationship and find that in the context of strong financing constraints, compared with the state-owned companies, the positive relationship between managerial overconfidence and corporate R \& D investment in the non-state-owned companies is stronger. In the robustness test, the dividend payout ratio is used as the proxy variable of financing constraints and then the regression test is carried out again. The research hypotheses are also supported and the conclusion is consistent.

The results of this paper show that the "irrational" psychology of managerial overconfidence has a positive side in corporate R \& D investment. When corporate R \& D investment faces more severe challenges (such as strong financing constraints), the psychological effect of overconfidence will be more prominent and thus its promoting effect on corporate R \& D investment is also more obvious. And this effect will be affected by ownership. It is an indisputable fact that China's capital market starts late, develops slowly and has many imperfections. It is difficult to improve these shortcomings in a short time, so companies will face serious financial constraints, especially small and medium companies, which will further affect companies' innovation activities. In recent years, the government has paid more and more attention to corporate innovation activities, introducing many related policies to stimulate corporate innovation investment. And with the process of economic globalization, the pressure of com- 
petition among companies is increasing, which highlights the importance of innovation. Therefore, in addition to external motivation, the companies should be based on their own situations and appropriately employ some overconfident managers, so that these managers can play an active role in innovation activities. However, as mentioned earlier, because managerial overconfidence cannot be directly observed, it is relatively difficult in the academic community to measure it accurately. So in reality, how to identify whether a manager is overconfident? One possible approach is to use personality test questionnaire to determine whether managers are overconfident. In order to ensure the quality of the questionnaire, we should seek the help of professional psychologists to design a sufficient professional psychological questionnaire.

The contribution of this paper is to introduce the variable of financing constraints, focusing on studying the relationship between managerial overconfidence and corporate $\mathrm{R} \& \mathrm{D}$ investment in the context of financing constraints. Financing constraints are very suitable for the current situation of China's capital market. In this context the research on the relationship between managerial overconfidence and corporate $\mathrm{R} \& \mathrm{D}$ investment has great practical significance. The main drawback of this paper is that it only studies the effect of managerial overconfidence on R \& D investment in the context of financial constraints and does not study its impact on R \& D output and subsequent performance. These problems can be further explored in the future.

\section{References}

[1] Galasso, A. and Simcoe, T.S. (2011) CEO Overconfidence and Innovation. Management Science, 57, 1469-1484. https://doi.org/10.1287/mnsc.1110.1374

[2] Hirshleifer, D., Low, A. and Teoh, S.H. (2012) Are Overconfident CEOs Better Innovators? The Journal of Finance, 67, 1457-1498. https://doi.org/10.1111/j.1540-6261.2012.01753.x

[3] Fairchild, R.J. (2005) The Effect of Managerial Overconfidence, Asymmetric Information, and Moral Hazard on Capital Structure Decisions. https://doi.org/10.2139/ssrn.711845

[4] Gervais, S., Heaton, J.B. and Odean, T. (2011) Overconfidence, Compensation Contracts, and Capital Budgeting. The Journal of Finance, 66, 1735-1777. https://doi.org/10.1111/j.1540-6261.2011.01686.x

[5] Taylor, S.E. and Brown, J.D. (1988) Illusion and Well-Being: A Social Psychological Perspective on Mental Health. Psychological Bulletin, 103, 193-210. https://doi.org/10.1037/0033-2909.103.2.193

[6] Camerer, C. and Lovallo, D. (1999) Overconfidence and Excess Entry: An Experimental Approach. American Economic Review, 89, 306-318. https://doi.org/10.1257/aer.89.1.306

[7] Pinfold, J.F. (2001) The Expectations of New Business Founders: The New Zealand Case. Journal of Small Business Management, 39, 279-285. https://doi.org/10.1111/0447-2778.00025

[8] Forbes, D.P. (2005) Are Some Entrepreneurs More Overconfident Than Others? Journal of Business Venturing, 20, 623-640. https://doi.org/10.1016/j.jbusvent.2004.05.001

[9] Knight, F.H. (1921) Risk, Uncertainty and Profit. Houghton Mifflin Company, Boston, 682-690.

[10] Griffin, D. and Tversky, A. (1992) The Weighing of Evidence and the Determinants of Confidence. Cognitive Psychology, 24, 411-435. https://doi.org/10.1016/0010-0285(92)90013-R

[11] Hao, Y., Liu, X. and Lin, C.N. (2005) An Empirical Research on the General Manager 
Overconfidence and Investment Decision for the Listed Companies. Chinese Journal of Management Science, 13, 142-148.

[12] Ye, B. and Yuan, J.G. (2008) Managerial Confidence, Corporate Investment and Firm Value: Evidence from Chinese Listed Companies. China Soft Science, No. 2, 97-108.

[13] Zhang, R.W. and Liu, W.X. (2008) An Empirical Study on Managerial Overconfidence and Earnings Management. The Theory and Practice of Finance and Economics, 29, 72-77.

[14] Hadlock, C.J. and Pierce, J.R. (2010) New Evidence on Measuring Financial Constraints: Moving beyond the KZ Index. Review of Financial Studies, 23, 1909-1940.

https://doi.org/10.1093/rfs/hhq009

[15] Chang, X., Fu, K., Low, A., et al. (2015) Non-Executive Employee Stock Options and Corporate Innovation. Journal of Financial Economics, 115, 168-188. https://doi.org/10.1016/j.jfineco.2014.09.002

[16] Ayyagari, M., Demirguc-Kunt, A. and Maksimovic, V. (2011) Firm Innovation in Emerging Markets: The Role of Finance, Governance, and Competition. Journal of Financial \& Quantitative Analysis, 46, 1545-1580. https://doi.org/10.1017/S0022109011000378

\section{Submit or recommend next manuscript to SCIRP and we will provide best service for you:}

Accepting pre-submission inquiries through Email, Facebook, LinkedIn, Twitter, etc.

A wide selection of journals (inclusive of 9 subjects, more than 200 journals)

Providing 24-hour high-quality service

User-friendly online submission system

Fair and swift peer-review system

Efficient typesetting and proofreading procedure

Display of the result of downloads and visits, as well as the number of cited articles

Maximum dissemination of your research work

Submit your manuscript at: http://papersubmission.scirp.org/

Or contact ojbm@scirp.org 